\title{
Metafora, metonímia és pragmatikai következtetés a grammatikalizációs jelentésváltozásban
}

\author{
Nagy C. Katalin \\ MTA-DE-SZTE Elméleti Nyelvészeti Kutatócsoport
}

\begin{abstract}
Összefoglaló
A tanulmány célja, hogy feltárja, milyen fogalmakat takarnak a metafora, metonímia, illetve pragmatikai következtetés terminusok a grammatikalizációs jelentésváltozás irodalmában, és megmutassa, hogy ezek értelmezése nemcsak az egyes elméleti megközelítésekben lehet más és más, hanem a szinkrón értelmezéstől is különbözik. Az elméleti fejtegetést az angol „be going to + főnévi igenév" mozgásigés szerkezetből kialakuló közeljövő grammatikalizációjának különböző elemzései illusztrálják. A vizsgálat, amely alapján a metaforának és metonímiának egy szinkrón és egy diakrón megközelítése bontakozik ki, azt látszik alátámasztani, hogy metonímia és metafora a grammatikalizációs jelentésváltozásban egymást kiegészítő pragmatikai folyamatokként összeegyeztethetőek. A kognitív metaforák hátterében álló, a világ tapasztalati megismeréséből adódó tudáson alapuló következtetési sémáink a grammatikalizációs jelentésváltozás irányát is megszabják.
\end{abstract}

Kulcsszavak: be going to; grammatikalizációs jelentésváltozás; implikatúra; jövő idő; metafora; metonímia; pragmatikai következtetés

\section{Bevezetés}

A grammatikalizáció kutatásának megélénkülése időben egybeesett a kognitív nyelvészeti és pragmatikai kutatások térnyerésével, így nem meglepő, hogy a grammatikalizációs jelentésváltozás hátterében álló kognitiv és pragmatikai folyamatok vizsgálata központi jelentőségű témává nőtte ki magát a modern szemléletű grammatikalizációkutatásban (vö. Ladányi 1998; 2005). Tanulmányomban a grammatikalizációs jelentésváltozás hátterében feltételezett kognitív folyamatokra vonatkozó terminológiát, nevezetesen a metafora, metonímia, illetve pragmatikai következtetés terminusok használatát vizsgálom meg. Célom, hogy rámutassak, hogy e terminusok mögött a grammatikalizációs jelentésváltozás kutatásában olyan fogalmak állhatnak, amelyek (i) mást és mást takarnak az egyes elméleti megközelítésekben, (ii) esetenként e fogalmak szinkrón értelmezésétől is különböznek, sőt (iii) az általuk leírt folyamatok a lexikai jelentésváltozás mechanizmusaitól is eltérőek lehetnek. Az elméleti fejtegetéseket egy konkrét nyelvtörténeti változás, az angol „be going to + főnévi igenév” mozgásigés szerkezetből kialakuló közeljövő grammatikalizációjának különböző elemzéseivel illusztrálom. A szakirodalom e népszerü példáját számos megközelítésben leírták, ezért alkalmasnak tűnik arra, hogy rajta e terminológiai és elméleti sokszínüséget megvizsgáljuk. Ráadásul a jövő idő 
jelölőjének kialakulása mozgásigés szerkezetekben a világ több nyelvéből adatolható, így az eredmények nagyobb valószínűséggel lesznek általánosíthatóak.

A tanulmány a következőképpen épül fel. A következő, 2. pontban általánosságban mutatom be a metafora és metonímia kognitív nyelvészeti megközelítését, és azt, hogy e fogalmak hogyan jelennek meg a grammatikalizációs jelentésváltozás történeti pragmatikai megközelítéseiben. A grammatikalizációs jelentésváltozás lehetséges elemzései alapulhatnak a (i) metafora vagy a (ii) metonímia fogalmán, (iii) ötvözhetik e két megközelítést, vagy pedig (iv) elvethetik mindkettőt. A tanulmány szerkezete e négy lehetséges irányvonalat követi. Elöször a metafora fogalmát veszem szemügyre a 3. pontban, ahogyan a kognitív nyelvészetben és a grammatikalizációkutatásban megjelenik, valamint egy történeti példa, az angol közeljövő kialakulásának egy metaforás elemzését is bemutatom (Sweetser 1988). A 4. pont foglalkozik a metonímiával, összevetve a kognitív nyelvészeti megközelítésben és a jelentésváltozás vizsgálatában megjelenő metonímiafogalom hasonlóságait és különbségeit. E pontban térek ki az implikatúra, pragmatikai következtetés és metonímia terminusokra, feltérképezve a mögöttük megbújó eltérő fogalmakat. $A z$ előző ponthoz hasonlóan a metonímia fogalmához kapcsolódóan is ismertetem a történeti példa egy vonatkozó megközelítését (Bybee 2007). Az 5. pont olyan elképzeléseket (Hopper-Traugott 1993; Heine-Claudi-Hünnemeyer 1991; Kearns 2002; Höfler-Smith 2009; Smith-Höfler 2015) gyűjt össze, amelyek ötvözik a grammatikalizációs jelentésváltozás metaforán, illetve metonímián alapuló elemzését. Végül a 6 . pontban a vizsgált jelentésváltozás egy mind a metafora, mind a metonímia fogalmát elvető megközelítésére (Pinto de Lima 1999) láthatunk példát. A 7. pont az elméleti megfontolások és a gyakorlati példaelemzések alapján körvonalazódó problémákat és következtetéseket foglalja össze, kitérve arra a kérdésre is, hogy az egyes megközelítések milyen adatokat vesznek figyelembe. A tanulmányban tárgyalt elméleti és gyakorlati megközelítések vizsgálata alapján a metaforának és metonímiának egy szinkrón és egy diakrón megközelítése bontakozik ki, amelyek hasonlóságait és különbségeit szintén e pontban érintem. Végül, a 8. pont a tanulmányban foglaltak összegzését és a konklúziókat tartalmazza.

\section{Metafora és metonímia a nyelv kutatásának kognitív és történeti megközelítéseiben}

A kognitív szemantikában a metafora és a metonímia olyan univerzális kognitív mechanizmusok, amelyek lehetővé teszik, hogy mindennapi tapasztalatainkból kiindulva megértsük és értelmezzük a világ különféle, elvontabb jelenségeit is (Lakoff-Johnson 1980; Johnson 1987; Langacker 2000; Győri 2007: 156-157). Ezen elméleti keretben tehát nem alakzatokként, hanem az elme müködésének mechanizmusaiként értelmezve őket fogalmi metaforáról és fogalmi metonímiáról beszélhetünk, amelyek bár nemcsak a nyelvhez köthetőek, különböző nyelvi jelenségeket motiválnak, és a nyelvhasználatban metaforikus és metonimikus kifejezések használatában nyilvánulnak meg. E mechanizmusok azonban nemcsak szinkrón szempontból érdekesek, hanem a nyelvi változás folyamatában is szerepet játszhatnak. A történeti szemantikában többek között Győri (2005) a lexikai jelentés változásának mechanizmusait kutatva megkérdőjelezhetetlennek tekinti, hogy csupán 
az emberi kognitív folyamatokra hivatkozva magyarázhatjuk kielégítően ezeket a változásokat. A szerző kiemeli, hogy a metaforát és a metonímiát, amelyek egyfelől a világ jelenségeinek konceptualizációjában kulcsszerepet játszó univerzális kognitív mechanizmusok, „a történeti szemantika a szemantikai változás két legfontosabb nyelvi mechanizmusának tekinti” (Győri 2005: 184). Győri (2005: 184) ugyanakkor hangsúlyozza, hogy „a változásnak a kiindulópontja a beszélők szinkrón nyelvi viselkedésében rejlik, pontosabban a szinkrón nyelvhasználatban előforduló jelentésmódosításokban (-módosulásokban) és -kiterjesztésekben, amelyek mögött a kognitív szemantika tárgyát képező kognitív folyamatok húzódnak meg”. Ez teszi lehetővé, hogy a történeti folyamatok vizsgálata által betekintést nyerjünk a nyelvhasználat során előforduló jelentésmódosítások mögött megbújó kognitív folyamatokba. Leírásában a metafora és a metonímia a jelentésbővüléssel és jelentésszűküléssel együtt a jelentésváltozás négy általános mechanizmusa között szerepel, és metaforikus, illetve metonimikus nyelvhasználaton alapul. Győri azonban a grammatikai jelentések kialakulására nem tér ki. Bár a grammatikalizációs jelentésváltozás magyar nyelvű szakirodalma is széleskörüen hivatkozik a folyamat kognitív hátterére, hasonló jellegü, rendszerező tanulmány magyar nyelven még nem született.

A grammatikalizációs jelentésváltozás történeti pragmatikai megközelítéseiben szintén alaptétel, amit fentebb Győritől idéztünk (Győri 2005: 184), miszerint „a változásnak a kiindulópontja a beszélők szinkrón nyelvi viselkedésében rejlik”, az azonban kérdéses, hogy a metafora és metonímia mechanizmusai ugyanúgy müködnek-e, mint a lexikai jelentésváltozásban. A vonatkozó szakirodalomban a grammatikalizációs jelentésváltozás hátterében álló kognitív folyamatokra való hivatkozás terminológiája nem egységes: a metafora, metonímia, pragmatikai következtetés terminusok jelentését mindig az adott kutatás elméleti keretének figyelembevételével lehet kikövetkeztetni, de gyakran még így is nehéz megállapítani, hogy pontosan milyen fogalmak állnak e terminusok mögött. Ráadásul e fogalmak eltérni látszanak a metafora és metonímia szinkrón értelmezésétől. Traugott és Dasher (2004 [2002]: 27) „metaforizációról” és „metonimizációról” beszélnek a jelentésváltozásban, hogy elhatárolódjanak e fogalmak szinkrón, statikus szemléletétől, és a metaforára és metonímiára mint mechanizmusokra utaljanak, folyamatbeli funkciójukat hangsúlyozva. Általában azonban terminológiailag nem szokás e kettőt elkülöníteni. A következő pontban a metafora jelenségét vizsgáljuk meg mind a szinkrón, mind a diakrón megközelítésben.

\section{Metafora}

\subsection{Metafora a kognitív nyelvészetben és a grammatikalizáció kutatásában}

A metafora a kognitív nyelvészetben különböző konceptuális tartományok közötti leképezés, amelynek segítségével a hozzájuk tartozó fogalmakat értelmezni tudjuk (Kövecses 2005: 20). Különbséget teszünk a fogalmi metafora így értelmezett jelensége és a metaforikus kifejezések között, amelyek a fogalmi metafora nyelvi megnyilvánulásai. A metafora a kognitív nyelvészeti értelmezésben az absztraktabb tartományok fogalmait segíti megérteni a konkrétabbakból kiindulva. Ehhez 
hasonlóan a grammatikalizáció szakirodalma a metaforát olyan mechanizmusként írja le, amely által a konkrétabb tartományokhoz tartozó nyelvi egységek absztraktabb egységekké, azaz grammatikai jelölőkké válnak. Nézzük meg egy történeti példa, pontosabban egy grammatikalizációs jelentésváltozás metaforán alapuló elemzését!

\subsection{Egy történeti példa: az angol közeljövö kialakulásának metaforás elemzése}

Az eredetileg mozgásigés „be going to + főnévi igenév” szerkezet grammatikalizáció útján közeljövő jelentésre tett szert az angolban. Századokkal ezelőtt ebben a célhatározói konstrukcióban az ige csak mozgásra utaló jelentésben volt értelmezhető. A jelenlegi nyelvállapotban azonban változatosság figyelhető meg, miszerint egyes előfordulásokban lehet szó mozgásra utaló jelentésről is (vö. John is going to visit Bill 'John megy, hogy meglátogassa Billt' / 'John meg fogja látogatni Billt'), míg más kontextusokban a jövő idő jelentés az egyetlen elérhető értelmezés (vö. Something is going to happen 'Valami történni fog'). Ez a grammatikalizációs jelentésváltozás nagyjából a 15-20. század között zajlott le, amikorra a fonetikailag rövidült forma (be gonna) is megjelent. A vizsgált angol mozgásigés szerkezet grammatikalizációja a világ több nyelvében adatolt ún. 'mozgás ösvényt' követi, amely a jövőidejüség jelentésének egyik széleskörüen feltárt grammatikalizációs útja: 'mozgás ösvény': mozgás egy cselekvés céljával > szándék > jövó (Bybee 2002: 181; vö. Heine-Kuteva 2002).

Az egyik lehetséges elemzés szerint a jövő idő jelölőjének valamely mozgásigéből történő kialakulása térből az időbe történő metaforikus leképezés eredménye. $\mathrm{E}$ nézetet Sweetser dolgozza ki részletesen 1988-as munkájában (Sweetser 1988). Célja az volt, hogy egy olyan egységes elméletet javasoljon, ahol a lexikai jelentésváltozás ugyanazokban a terminusokban írható le, mint a grammatikalizációs jelentésváltozás. Sweetser (1988) szerint a jelentésváltozás e fajtái egységesen kezelhetőek, a különbség abban áll, hogy szemben a gazdagabban strukturált lexikai jelentésekkel, a grammatikai jelentések általánosabbak olyan értelemben, hogy inherensen topologikusak és sematikusak. ${ }^{1}$ A lexikai jelentéseknek is vannak ugyanakkor topológiai aspektusaik, és éppen ezek azok, amelyek a grammatikalizáció során megőrződnek a metaforikus átvitel során, amikor egy tartalmas, lexikai egységből grammatikai egység alakul ki. A metaforikus átvitel a képisémaszerkezet megőrződését mutatja. ${ }^{2}$ A képiséma-metaforák, amelyek közül egyik a MOZGÁS, alapvető fizikai tapasztalataink alapján jönnek létre, és más fogalmak alapjául szolgálhatnak (Kövecses 2005: 52-53). A MOZGÁS képi-sematikus struktúrája tartalmazza a mozgás kiindulópontját, útvonalát és végpontját. A metaforán alapuló elemzés szerint a képiséma-szerkezetet vonjuk el a lexikai jelentésből, és AZ IDŐ TÉR fogalmi metafora alapján a céltartományba történő metaforikus átvitel során a céltartomány jelentése ehhez hozzáadódik. Így a go ige elveszíti fizikai mozgásra utaló jelentését, de elnyeri a jövőidejüség, szándék vagy előrejelzés jelentését (Sweetser 1988: 392).

\footnotetext{
${ }^{1}$ Sweetser e megállapításának forrásaként Talmy (1985)-öt és egyéb munkáit jelöli meg.

${ }^{2}$ A képiséma-szerkezet fogalmát Sweetser Lakoff (1987)-re hivatkozva említi; a megy képiséma-szerkezetéről és annak topológiai aspektusairól I. Sweetser (1988: 390-391).
} 
Feltehetjük a kérdést, hogy megvalósult-e az egységes leírás. Vajon a közeljövő kialakulása esetében ugyanarról AZ IDÖ TÉR metaforáról van szó, amelyről számos nyelvi kifejezés tanúskodik? Amikor Sweetser metaforáról beszél, úgy gondolom, hogy inkább metaforizációról, azaz metaforáról mint a nyelvi változás egy mechanizmusáról beszél. A probléma az, hogy míg a lexikai szemantikai változások esetében tényleges metaforikus nyelvhasználatról, azaz metaforikus kifejezésről van szó a kiinduló állapotban, így nemcsak mechanizmus értelemben beszélhetünk metaforáról, addig a grammatikalizációs jelentésváltozás esetében a térbeli és időbeli jelentést nem ritkán századok választják el egymástól. Lehet-e akkor egységes a leírás, ahogy Sweetser szeretné? A párhuzam akkor valósulhat meg, ha feltételezzük, hogy mindkét esetben valamiképpen a fogalmi metafora áll a háttérben. $E$ kérdésre a továbbiakban még visszatérünk. A metaforán alapuló elemzésnek a kritikája is hamar megjelent, a továbbiakban rivális elképzeléseket vizsgálunk meg, és áttérünk a metonímia témakörére.

\section{Metonímia és pragmatikai következtetés}

\subsection{A metaforás elemzés kritikája: a következtetéses modell}

A metaforán alapuló elemzés a mozgás általános jelentéséből indul ki, és bármely nyelvben érvényes lehet, ahol a mozgásigéből jövő idő jelölője alakult ki. Ezzel szemben más megközelítések hangsúlyozzák, hogy a jövő idő jelentés kialakulásának feltárásához mindig figyelembe kell venni az adott nyelv adott szerkezetének a morfoszintaktikai jellegzetességeit is, amelyben szerepelve a mozgásige grammatikai jelölővé vált, a „lexikai egység > grammatikai egység” séma a kontextusok figyelembevétele nélkül nem elég. A grammatikalizációs jelentésváltozás következtetéses megközelítése a metaforás magyarázat kritikáját adja.

A pragmatikai következtetések szerepét a jelentésváltozásban sokan vizsgálták. A szakirodalomban mára széles körben elfogadottá vált az a nézet, miszerint a társalgási implikatúrák konvencionalizálódása a grammatikalizáció folyamatának részét képezi, ahogyan a következő skála szemlélteti (I. Hopper-Traugott 1993; Traugott 1999; Levinson 2000; Kearns 2002; Traugott-Dasher 2004 [2002]):

(Grice 1989 [1975]; Traugott 1999; Levinson 2000) alkalmi társalgási implikatúra $\rightarrow$ általánosított társalgási implikatúra $\rightarrow$ konvencionális implikatúra $\rightarrow$ szemantikai/kódolt jelentés ${ }^{3}$

Ha még pontosabban akarunk fogalmazni, ahogyan Traugott és Dasher teszi, akkor egy lexikai egység konkrét kódolt jelentéséből indulunk ki, amely a gyakori használati kontextusok befolyásának köszönhetően az idő folyamán változáson mehet keresztül:

\footnotetext{
${ }^{3} \mathrm{Az}$, hogy a társalgási implikatúrák konvencionalizálódhatnak és beépülhetnek a kódolt jelentésbe, mára már nem újdonság. Ami újdonság, az az, hogy újabb kutatások megkérdőjelezik, hogy a folyamat pontosan úgy zajlik-e, ahogyan a skálán látható (Hansen-Waltereit 2006). E folyamat konkrét lépéseinek a feltárása a jelenlegi történeti pragmatikai kutatások egyik fontos témáját képezi. Jelen tanulmány szempontjából csupán az a fontos (és e tekintetben egyetértés van), hogy a nyelvhasználatban felmerülő pragmatikai következtetések befolyással bírnak a jelentésváltozásra.
} 
(2) (Traugott-Dasher 2004 [2002])

kódolt jelentés $\rightarrow$ megnyilatkozáspéldány-jelentés $\rightarrow$ megnyilatkozástípus-, pragmatikailag poliszém jelentés $\rightarrow$ új, szemantikailag poliszém (kódolt) jelentés

Amit a következtetéses modell a metaforás elemzéssel szemben hangsúlyoz, az az, hogy a kontextusbeli következtetések önmagukban, a metafora fogalma nélkül is magyarázzák a változást. Fontos még kiemelni azt is, hogy a változás fokozatosan, nem ugrásszerüen megy végbe, és hogy nagy jelentősége van a kétértelmű kontextusoknak, amelyekben a különböző jelentések együttesen lehetnek jelen. ${ }^{4}$ Nemcsak azt kell hangsúlyoznunk, hogy a két jelentés, a régi és az új együttesen jelen van egy adott nyelvállapotban, hanem hogy együttesen van jelen egyes konkrét használati kontextusokban is. Mielőtt az elemzést megvizsgálnánk a történeti példánkon, tegyünk egy kis terminológiai kitérőt: a következtetés fontosságát hangsúlyozó leírásokban ugyanis gyakran a pragmatikai következtetés és az implikatúra terminusok nem elkülönített használatát figyelhetjük meg.

\subsection{Implikatúra és pragmatikai következtetés}

A két fogalom nem elkülönített használata a történeti pragmatikában már a Hopper és Traugott szerzőpárosnak a grammatikalizáció témakörében alapműnek számító könyvében is felbukkan (Hopper-Traugott 1993). Hopper és Traugott szóhasználatában a pragmatikai következtetés és implikatúra terminusok keveredése arra vezethető vissza, hogy megközelítésükben igyekeznek ötvözni mind a beszélőre, mind a hallgatóra koncentráló nézeteket (Hopper-Traugott 1993: 64-67). A pragmatikai következtetés (pragmatic inference) és implikatúra (implicature) kifejezések szinonimaként való használatának indokaival kapcsolatban Kearns (2002: 2) Levinson (1983: 127) munkáját idézi, aki szerint Grice az implikatúra kifejezést általános terminusként, a mondott jelentéssel (what is said) való szembeállításban alkalmazta, és ilyen értelemben az érthető bármilyen, nem igazságfeltételes következtetésre vonatkozó megnevezésként. Tekintve a grice-i modell közismertségét, a társalgási implikatúra eredeti felfogásának átvételét látom célszerūnek. Az eredeti, grice-i megfogalmazás alapján a társalgási implikatúrának azon túl, hogy a mondott jelentéssel való szembeállításban fogalmazódik meg, egy másik fontos tulajdonsága is van, mégpedig a beszélői szándékhoz való kötöttsége. Mivel a szerzők az implikatúra és a pragmatikai következtetés terminusokat láthatólag szinonimaként használják, legalábbis explicite nem fejtik ki, hogy különbséget látnának közöttük, azt kell feltételeznünk, hogy az implikatúra terminust tágabb értelemben használják, mint a grice-i modell. Úgy vélem, hogy az implikatúra és a pragmatikai következtetés terminusok szinonimaként való használata nem követendő, mert félreértésekhez vezethet. Ezzel a problémával itt és most nem kívánok tovább foglalkozni, a továbbiakban az általánosabb értelmü pragmatikai következtetés terminust fogom használni, hiszen a nyelvi interpretáció folyamatában a hallgató nem feltétlenül a beszélő által szándékolt következtetésekre jut el, vagy nemcsak azokra, így a hallgatói következtetések leírásakor a társalgási implikatúra fogalma nem elegendő.

\footnotetext{
${ }^{4}$ A grammatikalizációs jelentésváltozáshoz köthető különböző kontextustípusokról I. Diewald (2002) és Heine (2002), a kontextus különböző értelmezéseiről a grammatikalizációban I. Nagy C. (2014).
} 
Ami témánk szempontjából fontos, az az, hogy Hopper és Traugott az implikatúrák müködését a nyelvi változásban metonimikus folyamatokként írják le, és a metafora működésével való szembeállításban értelmezik. Nézzük meg, hogy a metonímia ilyen értelmezése milyen viszonyban van a metonímia kognitív nyelvészeti értelmezésével!

\subsection{A metonímia kognitív nyelvészeti és történeti értelmezése}

A kognitív nyelvészetben „a metonímia olyan kognitív folyamat, ahol egy közvetítőfogalom (tárgy, esemény, tulajdonság stb.) mentális hozzáférést ${ }^{5}$ biztosít egy olyan célfogalomhoz (tárgyhoz, eseményhez, tulajdonsághoz stb.), amely ugyanannak a fogalmi keretnek, (fogalmi) tartománynak, vagyis idealizált kognitív modellnek (IKM) a része" (Kövecses-Benczes 2010: 65). Bencze (2010: 114) megállapítja, hogy „Számos szerző már nemcsak a »hagyományos « metonímiákat tekinti a jelenség körébe tartozóknak, hanem minden olyan nyelvi és nem nyelvi, konceptuális esetet is, amelyekben valamilyen formában tetten érhető a (lakoffi értelemben vett) idealizált kognitív modelleken belüli helyettesítési eljárás". Ennek megfelelően a metonímia jelenségének körébe sorolhatóak a diskurzus szintjén történő pragmatikai következtetések is.

A metonímia képessége, mint amely „szokásosan együtt előforduló, egymással érintkező jelenségek reprezentációinak a mentális rendszerben való összekapcsolódásán alapul” (Reszegi 2011: 80), az egyazon kontextusban együttesen előforduló jelentésekre is kiterjeszthető. Ez a grammatikalizációs jelentésváltozásban a következőképpen jelenik meg, ahogyan Bybee (2007: 977) jól érthetően megfogalmazza: „a pragmatikai következtetésből eredő változást metonimikus folyamatnak tartják, mert egy (következtetésböl származó) jelentés, amely gyakran kapcsolódik egy konstrukcióhoz, végül a konstrukció egyik jelentésévé válik." ${ }^{\circ}$ Traugott és König (1991: 211) már jóval korábban a metonímia fogalmának kiterjesztését javasolják „a hagyományos konkrét és nyílt kontextusokról a kognitív, rejtett kontextusokra, különösképpen a társalgási és konvencionális következtetések pragmatikai kontextusaira. A szomszédosság ilyen módon a diskurzus világában van jelen." 7 A metonímia fogalmában eredetileg jelen lévő szomszédosság a grammatikalizáció irodalmában tehát a különböző jelentések „szomszédosságára”, együttes jelenlétére utal a használati kontextusban. ${ }^{8}$ A metonímia a grammatikalizációs jelentésváltozás irodalmában általában a metaforával való szembeállításban jelenik meg. A metafora és az implikatúrák szerepét vizsgálva a jelentésváltozásban Kearns (2002) felhívja a figyelmet arra, hogy a metafora, metonímia és implikatúra terminusok a

\footnotetext{
${ }^{5} \mathrm{~A}$ „mentális hozzáférés” általános megfogalmazással szemben mások a metaforához hasonlóan a metonímia esetében is leképezésröl (mapping) beszélnek (I. Barcelona 2003).

${ }^{6}$ "Change from pragmatic inference is considered a metonymic process, since a meaning (from the inference) that is often associated with a construction becomes one of the meanings of the construction."

7 "[We propose extending the notion of metonymy] from traditional concrete and overt contexts to cognitive and covert contexts, specifically the pragmatic contexts of conversational and conventional inference. The contiguity involved is based in the discourse world."

${ }^{8} \mathrm{E}$ kétféle szomszédosságot részletesebben, példákkal illusztrálva is megvizsgáljuk majd a 7.2. pontban.
} 
grammatikalizációs irodalomban különböző fogalmakat fejezhetnek ki. Egyesek az implikatúrát és a metonímiát egy csoportba sorolva állítják szembe a metaforával, arra hivatkozva, hogy míg előbbi kettő a jelentések szomszédosságán alapul, a metafora a jelentések hasonlóságán vagy analógián. Bár Kearns maga különbséget tesz implikatúra és metonímia között, a legszélesebb körben elterjedt nézet az, hogy a nyelvhasználat konkrét kontextusaiban felmerülő implikatúrák metonimikus természetűek, így ez a nézet a kettőt együtt állítja szembe a metaforával. Tanulmányomban ez utóbbi megközelítést követem. Így tekintve a központi kérdés az marad, hogy vajon a jelentésváltozásban a metafora, vagy pedig a metonímia/pragmatikai következtetés játssza-e a főszerepet. A grammatikalizációs jelentésváltozásban szerepet játszó metaforikus és metonimikus folyamatok egymáshoz való viszonyával foglalkozik még Hopper és Traugott (1993: 77-87), valamint magyarul Dér (2008: 24-26). A grammatikalizációs irodalomban tehát az implikatúrán/pragmatikai következtetésen alapuló jelentésváltozást a jelentések szomszédosságán alapuló metonimikus folyamatként értelmezve a metaforikus változással állítják szembe, ami viszont a jelentések hasonlóságán vagy analógián alapul (vö. Kearns 2002). Így hát széleskörüen vizsgálják a metaforikus és metonimikus folyamatok egymáshoz való viszonyát, amely a változás ugrásszerű vs. fokozatos természetével is összefügg.

\subsection{A „be going to + főnévi igenév” szerkezet grammatikalizációja a következtetéses modellben}

A metaforás elemzés egy példáját már láttuk fentebb, tekintsük most az angol szerkezet változásának elemzését a következtetéses modellben Bybee (2007) alapján! Bybee (2007: 976) úgy véli, hogy míg a metafora inkább a lexikai jelentésváltozás jelentős mechanizmusa, a grammatikalizációban a pragmatikai következtetési folyamatok játszanak nagyobb szerepet, az implikatúrák konvencionalizálódása által. Bybee (2007: 965-979) hangsúlyozza, hogy a grammatikalizáció meghatározott konstrukciókban zajlik, és új konstrukciók kialakulásához vezet. ${ }^{9}$ E felfogás szemben áll a metaforás megközelítéssel, amely csupán a go lexémát önmagában veszi figyelembe. Az angol közeljövő kialakulása olyan konstrukcióban zajlott le, ahol a go 'megy' mozgásige folyamatos alakját (be going) a szerkezet másik igei elemével a to prepozíció kapcsolja össze. A folyamat fokozatosan következik be, és mind alakbeli, mind funkcióbeli változatosság kíséri. A korai kontextusok közül azokban, ahol a be going to szerkezetet igei elem követi, a térbeli mozgás jelentésén túl igen erősen jelen van egy következtetés a 'szándék' jelentésre is. Ez a későbbiekben előtérbe kerül, és így egy jövőbeli cselekvésre való következtetés válik lehetségessé. Ennek megfelelően a He's going to (gonna) buy a house 'Házat akar / fog venni' állíthat egy szándékot is, vagy pedig egy jövőbeli cselekvést jósolhat meg (Bybee 2007: 968). Bybee a változás fokozatosságát, lassú lezajlását hangsúlyozza, és amellett érvel, hogy a metaforikus változásnak tűnő grammatikalizációs jelentésváltozások többsége valójában inkább az implikatúráknak a gyakori használat eredményeként bekövetkező konvencionalizálódásával függ össze.

\footnotetext{
${ }^{9}$ Hasonlóan érvel Hopper és Traugott (1993) is, I. az 5.1. pontban.
} 
Figyeljük meg, hogy Bybee nagy hangsúlyt fektet elemzésében a kétértelmű előfordulásokra, amelyekről a metaforás megközelítésben sokkal nehezebb lenne számot adni (vö. a 7.2. pontban írottakkal). Ezekben a kontextusokban az új értelmezéshez következtetés útján jutunk el, de még a régi jelentés is tulajdonítható. Bybee egyik példája, a szakirodalomban amúgy is gyakran felbukkanó, Shakespeare egyik munkájában található előfordulás:

(1595, Shakespeare, Two Gentlemen of Verona III.i.51) ${ }^{10}$

Duke. Sir Valentine, whither away so fast?

Val. Please it your grace, there is a messenger

That stays in to bear my letters to my friends,

And I am going to deliver them.

Bybee a következőképpen elemzi a példát. A kérdés szó szerinti tartalma egyértelműen a térbeli mozgásra vonatkozik, a válaszban azonban inkább az alany szándékára történik utalás, mint térbeli mozgásra. Ez a válasz megfelelő, hiszen a herceg valójában Valentin szándékára kíváncsi. Tehát „nem egy a térbeli jelentésről az időbelire való közvetlen váltásról van szó, hanem inkább a térben történő mozgás kifejezése felöl a szándék kifejezése felé történik elmozdulás. Később következtetésnek köszönhető változás történik a szándék felől az elörejelzés, azaz a jövő felé"11 (Bybee 2007: 979). Az elemzett kontextusban azonban még tulajdonítható a mozgás jelentés is. Az ilyen átmeneti kontextusok megléte a grammatikalizációs jelentésváltozás kiemelkedően fontos tényezője (vö. Heine 2002).

\section{A metaforán és a metonímián alapuló elemzés ötvözése}

A két modell úgy tűnik, összeegyeztethető. Egyrészt az időbeli jelentések kialakulása térbeli jelentésekből univerzális tendenciát mutat, a világ számos nyelvéből adatolható, másrészt ezen folyamatokban az átmeneti kontextusok, amelyek pragmatikai következtetési folyamatokat váltanak ki, megkérdőjelezhetetlenül jelen vannak. Így felmerült az igény, hogy a grammatikalizációs jelentésváltozás következtetéses folyamatokon, azaz metonímián alapuló elemzését valahogyan ötvözzük a metaforás elemzéssel, amely viszont a TÉR és IDŐ kapcsolatát helyezi előtérbe. A következőkben a szakirodalomban fellelhető különböző megoldásokat vizsgálunk meg, a teljesség igénye nélkül.

\subsection{Hopper és Traugott (1993)}

Hopper és Traugott (1993: 81, 84) úgy vélik, hogy a metafora központi szerepét annak köszönheti, hogy a kutatók a "lexikális egység > grammatikai egység"

\footnotetext{
${ }^{10} A$ két veronai nemes Szabó Magda általi fordításából éppen a minket érdeklő igei rész hiányzik, ezért azt csak lábjegyzetben adom meg: „HERCEG: Valentin úr, hová olyan sietve? VALENTIN: Kegyelmes úr, útrakész a futár, Csak a leveleimet várja még, Amelyeket rokonaimnak írtam."

11 „rather than a switch directly from a spatial to a temporal meaning, we have a move from the expression of movement in space to the expression of intention. Later, an inferential change can take intention to prediction, that is, future."
} 
sémában gondolkodnak, a kontextusok figyelembevétele nélkül. Ök ezzel szemben hangsúlyozzák, hogy nem a go grammatikalizálódott, hanem a be going to szerkezet, helyi kontextusokban, ahol a to célhatározói szerepe is közrejátszott. A metaforára támaszkodó leírás szerintük nem ad magyarázatot arra, hogy más nyelvektől eltérően miért éppen ez a progresszív szerkezet grammatikalizálódott, éppen ezzel a prepozícióval. Véleményük szerint a helyi kontextusokban lehetséges következtetések és az ige helye határozzák meg az egyes szerkezetek eltérő történetét a különböző nyelvekben.

(Hopper-Traugott 1993: 88) John is going to visit Bill. John is going to like Bill.

\begin{tabular}{|c|c|c|}
\hline I. szakasz: & $\begin{array}{ll}\text { be } & \text { going } \\
\text { PROG } & V_{\text {dir }}\end{array}$ & $\begin{array}{l}\text { [to visit Bill] } \\
\text { Purpose clause }^{12}\end{array}$ \\
\hline II. szakasz: & $\begin{array}{l}\text { [be going to] } \\
\text { TENSE }\end{array}$ & $\begin{array}{l}\text { visit Bill } \\
\mathrm{V}_{\mathrm{act}} \\
\text { (szintaktikai újraelemzés/metonímia útján) }\end{array}$ \\
\hline III. szakasz & $\begin{array}{l}\text { [be going to] } \\
\text { TENSE }\end{array}$ & $\begin{array}{l}\text { like Bill } \\
\mathrm{V}_{\text {state }}{ }^{3} \\
\text { (analógia/metafora útján) }\end{array}$ \\
\hline
\end{tabular}

A dilemma mélységét mutatja, hogy bár a szerzők végig a metaforás elemzés ellen érvelnek, a végén mégsem vetik el teljesen a metafora szerepét, és megjegyzik, hogy „a térből az időbe való metaforaalkotás képessége valószínűleg olyan kognitív keretként szolgál, amely elősegíti e folyamatokat"14 (Hopper-Traugott 1993: 84). Az is sokatmondó, ahogyan az elemzésüket összefoglaló, fentebb idézett ábrán mégiscsak felbukkan a metafora, amikor a következő elképzelést fejtik ki: a szerkezet újraelemzésében, a grammatikalizációs folyamat kezdetén a metonimikus, következtetéses folyamatok játszanak szerepet jól körülírható pragmatikai és szintaktikai kontextusokban, míg a metaforikus folyamatok csak később, a szerkezet használatát érintő paradigmatikus változásokban jelennek meg. Úgy vélik, a két folyamat nem kizárja, hanem kiegészíti egymást, a következtetéses folyamatok a lineáris, szintagmatikus tengelyen, míg a metafora a paradigmatikus tengelyen okoz változásokat. Azt, hogy a használat több igetípusra általánosult, analogikus folyamatnak tartják, és mint ilyet, a metaforával hozzák kapcsolatba. Homályban marad azonban ennek a metaforának a természete. Metaforikus kifejezésről szó van-e? Vagy csak „keretet ad”, de mit jelent ez pontosan? A leírás hiányossága tehát, hogy miután a metafora fogalmát visszacsempészték a leírásba,

12 célhatározói tagmondat

${ }^{13} \mathrm{Az}$ ige (V) glosszájának alsó indexei mozgásigére (dir), cselekvést leíró igére (act) és állapotot kifejező igére (state) utalnak. Az új igetípus megjelenése a konstrukcióban a grammatikalizáció elörehaladását mutatja.

${ }_{14}$ "[In each case inferences from the highly local contexts of the verb in its linear position within the clause appear to be the immediately motivating factors for change, though] the capacity to create metaphors of time from space may well provide a cognitive framework that supports the changes." 
nem fejtik ki, mit is értsünk alatta, és hogy pontosan hogyan működik közre a metafora a paradigmatikus tengelyen a konkrét nyelvhasználatban.

\subsection{Heine-Claudi-Hünnemeyer (1991) ${ }^{15}$}

Heine-Claudi-Hünnemeyer (1991) szerint a grammatikai kategóriák létrejötte konceptuális műveletek eredménye, amelyeknek köszönhetően az absztrakt fogalmakat a konkrétabbak terminusaiban értjük meg. Ez a folyamat, azaz maga a konceptualizáció, metaforikus. A szerzők szerint a folyamat jól jellemezhető néhány alapkategória segítségével, amelyek lineáris elrendeződést mutatnak: mindegyik alapul szolgálhat a tőle jobbra eső kategória konceptualizációjához: SZEMÉLY > TÁRGY $>$ FOLYAMAT > TÉR > IDŐ > MINÖSÉG. ${ }^{16}$ A kategóriák azonban nem határolódnak el élesen egymástól, ami pedig összekapcsolja őket a grammatikalizációban, az a „kontextus-indukált újraértelmezés”. Így Heine és munkatársai a metaforás elemzést megtartva megpróbálják leírásukba belecsempészni a metonímiát is, amikor azt a következtetést vonják le, hogy mind a metafora, mind a metonímia jelen van a grammatikalizációban, és attól függően, hogy milyen szemszögböl tekintünk a folyamatra, egyiket vagy a másikat látjuk müködni. A metafora müködését látjuk, ha a jelentésváltozást makroszinten vizsgáljuk, és a metonímiát, amikor mikroszintű nézőpontból nézzük (vö. Kearns 2002). A metafora így nem más, mint az ismétlődő kontextusbeli következtetési folyamatok kimenete (outcome), vagy ahogy máshol fogalmaznak: „metonimikus kiterjesztések sorozatának eredménye” ${ }^{17}$ (HeineClaudi-Hünnemeyer 1991: 165).

\subsection{Kearns (2002)}

Az implikatúrára és a metaforára való utalás együttesen van jelen Kearns (2002: 14) elemzésében is. A szerző úgy írja le a jövő idő kialakulását, hogy először a mozgás jelentést is megengedő kontextusokban merül fel egy előrejelzés implikatúra útján. Erre példája a They are going to sell their wares at the market 'Mennek, hogy eladják áruikat a piacon', ahol a szó szerinti, mozgásra utaló jelentés ('Úton vannak a piacra, hogy eladják áruikat') a jövő idő jelentést implikálja. Kearns (2002: 14) elképzelése szerint a továbbiakban, amikor a kifejezés már a szó szerinti, egy cél felé tartó mozgás jelentést kizáró kontextusban is használatossá válik (pl. It's going to rain '(Hamarosan) esni fog'), „metaforikus leképezés bontakozik ki a TÉRBEN VALÓ MOZGÁSról az IDÖBEN VALÓ MOZGÁSra."18 Ezt a kettős, mind a pragmatikai következtetésekre, mind a metaforára építő elemzéssel leírható jelenséget nevezi Kearns az „emergáló metafora” (emerging metaphor) általános mintázatának. Meg kell azonban jegyeznünk, hogy a szerkezet történetére vonatkozó adatok arra utalnak, hogy az It's going to rain típus később jelenik meg, mint a mozgás értelmezést is lehetővé tevő előfordulások. Az It’s going to rain példa és hasonló társai nem igényelnek metaforikus elemzést, amennyiben úgy értelmezzük őket, mint amelyek akkor válnak lehetségessé és akkor jelennek meg a

\footnotetext{
${ }^{15}$ A szerzők grammatikalizációs jelentésváltozással kapcsolatos elképzeléseiről magyar nyelven jó összefoglalót ad Ladányi (1998: 407-411).

${ }^{16}$ PERSON > OBJECT > PROCESS > SPACE > TIME > QUALITY

17 "the result of a number of metonymic extensions"

18 "a metaphorical transfer of MOTION IN SPACE to MOTION IN TIME emerges"
} 
nyelvhasználatban, amikor a jelentésváltozás már lezajlott. A mozgás jelentés ugyanis ezekben a használatokban már nincs jelen. Mivel a kérdéses nyelvi egység eddigre már új jelentésre (ti. jövő idő jelentésre) tett szert, leírásakor nem szükséges a metaforikus leképezés fogalmához folyamodnunk. Az „emergáló metafora” fogalma hasonló Heine-Claudi-Hünnemeyer (1991) fentebb bemutatott nézetéhez, miszerint a következtetési folyamatoknak köszönhető jelentésváltozás végeredménye leírható a metafora terminusaiban. Tehát az emergáló metafora nem egy konkrét metaforikus kifejezésre utal egy konkrét használati kontextusban, hanem egy történeti folyamatra, és ez a metaforafogalom ugyancsak eltér a metafora szinkrón értelmezésétől. Az emergáló jelző éppen ezt mutatja: hogy lassan kibontakozó, nem egyetlen nyelvhasználóhoz köthető metaforikus folyamatról van szó.

\subsection{Metafora és metonímia a grammatikalizációs jelentésváltozás relevanciaelméleti megközelítésében}

A metafora és a metonímia szembenállása nem minden elméleti keretben értelmezhető. Höfler és Smith (2009), valamint Smith és Höfler (2015) a jelentésváltozás leírásában két modell között tesznek különbséget, a metaforán és az újraelemzésen alapuló között. Véleményük szerint a különbség abban áll, hogy a hallgató által kikövetkeztetett új jelentést a beszélőnek szándékában állt-e közvetíteni vagy sem. Feltevésük szerint a hallgató ${ }^{19}$ mindkét esetben ugyanazon a következtetési soron halad végig, amely az ő relevanciaelméleti keretükben a metaforán alapuló forgatókönyv esetében a következőképpen néz ki:

(5) (Höfler-Smith 2009: 890, 891; I. még Smith-Höfler 2015: 135-137) „egy beszélő SZÁNDÉK kifejezését szándékolja. A TÉRI MOZGÁSt kifejező formát metaforikusan használja."

„Hallgató:

(g) A beszélő térbeli mozgást fejezett ki.

(h) A térbeli mozgás nem releváns az adott kontextusban.

(i) A térbeli mozgás gyakran SZÁNDÉKot implikál.

(j) A SZÁNDÉK releváns lenne az adott kontextusban.

(k) Feltételeznem kell, hogy a beszélő együttmüködő.

(I) Azt is feltételeznem kell, hogy a beszélő tudatában van annak, hogy én tudom (g)-(k)-ban foglaltakat, és tudom, hogy ő tudatában van ennek.

(m) A (g)-(l)-ben foglaltak alapján arra következtetek, hogy a beszélő szándékot akar kifejezni." 20

\footnotetext{
${ }^{19}$ A szerzők természetesen a beszélő gondolatmenetét is bemutatják, de itt most csak a hallgató oldalát idézem, amely a tanulmány szempontjából releváns.

20 „A speaker intends to express INTENTION (3a). She uses the form for SPATIAL MOTION metaphorically." „[Speaker expresses SPATIAL MOTION], Hearer: $(\mathrm{g})$ the speaker has expressed SPATIAL MOTION. (h) SPATIAL MOTION is not relevant in the given context. (i) SPATIAL MOTION often implies INTENTION. (j) INTENTION would be relevant in the given context. (k) I must assume that the speaker is co-operative. (I) I must also assume that the speaker is aware that I know $(\mathrm{g})-(\mathrm{k})$, and that I know of his being aware of it. $(\mathrm{m})$ From $(\mathrm{g})-(\mathrm{l})$, I conclude that the speaker intends to convey intention." (Höfler-Smith 2009: 890, 891)
} 
Az idézett elemzésben szembeszökő, hogy nem a holista kognitív nyelvészetből ismert metaforafogalommal van dolgunk. Az eddigiekhez képest ez egy teljesen eltérő metaforafelfogás, ahol a metafora és a következtetések közötti határ összemosódik. A metafora és a pragmatikai következtetések fogalmának teljes összefonódása Höfler-Smith (2009), valamint Smith-Höfler (2015) megközelítésében annak tudható be, hogy a szerzőpáros a nyelvhasználatot az osztenzív-következtetéses kommunikáció modelljére alapozva úgy képzeli el, hogy minden megnyilatkozás elhelyezhető egy szószerinti-metaforikus kontinuumon, amely a konvencionális jelentéstől való eltérés mértékének megfelelően jellemzi a nyelvhasználatot, így a metafora minden figuratív használatot, köztük a metonímiát is magában foglalná. ${ }^{21}$ Amellett érvelnek, hogy minden nyelvi szerkezet levezethető valamely konvencionalizálódott metaforából: az osztenzív megnyilatkozások jelentését a nyelvhasználó az adott kontextusban ad hoc következteti ki, és ezen alkalmi jelentések memorizálása, majd későbbi újbóli alkalmazása útján a gyakori használatnak köszönhetően jön létre a konvencionalizáció és az elsáncolás (entrenchment ${ }^{22}$ ).

Figyeljük meg, hogy a szerzők által felvázolt következtetési séma nem feltételezi, hogy a hallgató bármiféle fogalmi metaforára támaszkodna a szándékolt jelentés kikövetkeztetésekor. Véleményem szerint a szakirodalom ilyen bemutatása félrevezető olyan szempontból, hogy a szerzők a metaforikus elemzéseket a saját elméleti keretükbe átültetve interpretálják, amely azonban nem ismeri el a fogalmi metaforákat más kognitív nyelvészeti megközelítésekben szokásos értelemben. Ugyanakkor a szerzők metaforikus nyelvhasználatot feltételeznek a beszélő részéről, ez azonban csak a saját elméleti keretükben minősül annak, más megközelítésekben nem. A metaforára támaszkodó modellek ilyen jellemzése félrevezető lehet, a leírás azonban jól megragadja a grammatikalizációban nagy jelentőséggel bíró, átmeneti kontextustípusban feltehetőleg lezajló következtetési folyamatokat, amelyek egy új jelentés kialakulásához vezethetnek. Az ilyen kontextusokban ugyanis lehetséges a mozgás jelentés, de nem tűnik relevánsnak a hallgató számára, aki egy másik, relevánsabb értelmezést keres. Ilyen értelemben a szerzőpáros elképzelése inkább a grammatikalizációs jelentésváltozás következtetéses, metonímiára építő modelljeihez sorolható, még ha a metafora terminust alkalmazzák is.

\section{A grammatikalizációs jelentésváltozás leírása a metafora és metonímia fogalmai nélkül}

Végül térjünk át egy olyan elemzésre, amely nem kíván támaszkodni sem a metafora, sem a metonímia fogalmára: Pinto de Lima $(1999)^{23}$ szerint a nyelvi változatosság

${ }^{21}$ Smith-Höfler (2015: 126): „This continuum from literal to figurative, metaphorical language use also encompasses phenomena such as metonymy. (...) The figurative continuum can therefore be defined in terms of how much of the conventional meaning is disregarded, and how flagrantly these disregarded components clash with the actual meaning communicated." 22 Tolcsvai Nagy (2005: 28) definíciója szerint az entrenchment (magyar megfelelője: elsáncolás vagy begyakorlás) „valamely fogalom elmebeli körülhatárolódását és viszonylag könnyủ előhívhatóságát (aktiválhatóságát) nevezi meg".

${ }^{23}$ A grammatikalizációs jelentésváltozás azon megközelítései közül, amelyekben nem kap szerepet a metafora és a metonímia, jelen tanulmányban Pinto de Lima (1999) elképzelését 
és analógia fogalmai elegendőek a folyamat magyarázatához. Pinto de Lima (1999: 209) hangsúlyozza, hogy a grammatikalizációs jelentésváltozás egy hosszú történeti folyamat, amely kicsi köztes lépésekből tevődik össze, és a metaforának csupán az illúziójáról van szó. E kicsi köztes lépéseket általában metonimikus jellegű változásként írják le. Pinto de Lima úgy véli, mivel ezek önmagukban kielégítő magyarázatot nyújtanak a változásokra, nincs szükség a metaforára. A szerző azonban a metonimikus elemzést is részletesen górcső alá veszi. Hangsúlyozza, hogy a jövő időre való utalás következtetésként már a kezdetektől, a szerkezet 'mozgás' jelentéssel való használatakor is jelen van a kontextusban, amennyiben a go ige előfordulását cselekvést leíró főnévi igenév követi, a két igei elemet pedig a to célhatározói prepozíció köti össze. Hiszen amikor a beszélő az alany valamely cselekvés végrehajtásának céljával történő mozgását írja le, arra következtetünk, hogy a cselekvés feltehetöleg megvalósul a jövőben.

A mozgásige prototipikus használatában az alany ágensi természetű és szándékkal rendelkező, a főnévi igenév pedig szándékosan végrehajtható cselekvést ír le. Pinto de Lima (1999: 214) az ettől eltérő előfordulásokat nem metonimikus változásként értelmezi, hanem úgy, hogy a beszélők eltérnek a prototipikus használattól, ami a prototipikus jellemzők eróziójához vezet, míg végül a mozgásra már nem is történik utalás. Mindebben az analógia szerepét hangsúlyozza. Elemzésének tehát két sarokköve: a nyelvi változatosság és az analógia, amelyek véleménye szerint önmagukban magyarázzák a folyamatot. Pinto de Lima hangsúlyozza, hogy a folyamat végére már nem vezethetjük le a jövőidejüséget a 'mozgás' jelentésből, hiszen ekkorra mozgásra való utalás már nincs is jelen. A jelentés megváltozását a jelentés egyes jegyeinek (features) elvesztésével magyarázza:

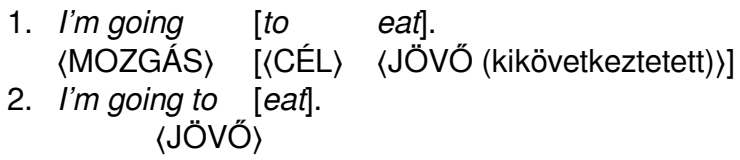

A jelentésváltozás egymást követő fázisaihoz köthetőek a következő megnyilatkozások, amelyek egy-egy tipikus használatot mutatnak be Pinto de Lima (1999) alapján: I'm going to see a doctor (hangsúly a főnévi igenévben foglalt cselekvésen), I'm going to fall into a trap (nem lehet szó szándékosságról), $A$ war is going to come (nem élő alany). ${ }^{24}$

Pinto de Lima (1999: 216) megállapítja, hogy a hagyományos értelemben vett metonímia, amely a jelentések (nyelven kívüli világban való) szomszédosságán alapul, semmiképpen nem játszik itt szerepet. Ehhez szerinte egy olyan beszélőt kellene elképzelnünk, aki 'mozgás' és 'jövőidejüség' értelemben használja a

emelem ki, mert ő veszi kritikusan és részletesen górcső alá a metaforán, illetve metonímián alapuló elemzéseket. Természetesen más leírások is léteznek, mint pl. a jelen tanulmány egyik lektora általa kiemelt Langacker (2000), aki kognitív keretben értelmezve a be going to szerkezet jelentésváltozását, azt a szubjektifikáció folyamatának egy példájaként mutatja be.

24 Úgy vélem a MOZGÁS jegy elvesztését e keretben úgy kell értelmeznünk, hogy a jelentésváltozás előrehaladottabb állapotában már léteznek (lehetségesek) olyan kontextusok, amelyekben nincs jelen. A vizsgált esetben azonban a mai napig vannak olyan kontextusok is, amelyekben megőrződik (I. az első példát a három közül). 
szerkezetet, és azáltal csupán a jövőidejüség jelentését akarja közvetíteni. De ilyen beszélő nincs: senki sem akarja a mozgást jelentő szerkezetet pusztán jövő idő értelemben használni. Megoldásként kínálkozik a metonímia fogalmának kiterjesztése, ahogyan már Traugott és König (1991: 211, idézi Pinto de Lima 1999: 217, I. fentebb 4.3.-ban) is utalt rá, akik hangsúlyozzák, hogy a szomszédosságot ebben az esetben a diskurzus világában kell elképzelni. Pinto de Lima azt is kiemeli, hogy a jövő idő jelentésének megjelenése ${ }^{25}$ azonban semmi esetre sem köthető a beszélő szándékához, e jelentés megjelenése csupán annak nem szándékolt következménye, hogy a 'mozgás' és 'cél' jelentések fokozatosan elvesztették jelentőségüket. A beszélők nem szándékolták a jövő idő jelentés „kialakítását”, csupán bizonyos kommunikatív céljaik voltak, mint pl. a főnévi igenévben leírt cselekvés hangsúlyozása. Ezek következtében gyakoribbá vált a szerkezet használata olyan kontextusokban, ahol a mozgás és a cél kisebb vagy semmilyen szerepet sem játszott, ami a jövő idő jelentés szemantikaivá válásához vezetett - akarattalanul.

Vegyük észre, hogy Pinto de Lima ezen okfejtése a metonímiának egy olyan felfogásán alapul, amely eltér a történeti kutatásban megjelenő, fentebb bemutatott értelmezéstől. ${ }^{26}$ Egyrészt az, hogy a beszélők nem szándékolták a jövő jelentés kialakulását, önmagában nem probléma. Amikor valamilyen metonimikus vagy metaforikus nyelvi kifejezést használunk, akkor sem célunk, hogy a használt nyelvi elem kódolt jelentése megváltozzon. A jelentésváltozásról általánosságban elmondható, hogy közvetlenül nem köthető a beszélők szándékaihoz. Ugyanígy, itt is elegendő, ha valamely esemény jövőbeni bekövetkeztét sugallni szándékozzuk. Az, hogy ezt a használatot mások is követik, és ez a jelentés később kódolttá válik a gyakori használat és ezáltal a konvencionalizáció révén, természetesen nem célja a nyelvhasználónak. Másrészt a jelentésváltozás fokozatos: nem egyből a jövőidejüség jelenik meg, hanem elöször a szándék.

Végül Pinto de Lima arra a következtetésre jut, hogy a metonímiát csak nagyon általánosan lehet érteni ebben a folyamatban: együttesen megjelenő jelentésekről van szó, amelyek azonban eltérő státuszúak: egyesek szemantikaiak, míg mások csupán kikövetkeztetett jelentések, és a státusz átviteléröl van szó: a kikövetkeztetett jelentések szemantikaivá válnak, míg a szemantikaiak eltűnnek. Ez az elképzelés a metonímia fentebb már bemutatott történeti értelmezésének felel meg (I. még később 7.2.-ben is).

Ha alaposan utánagondolunk, Pinto de Lima (1999) érvelése végeredményben azon alapul, hogy egy hosszú, évszázadokon át zajló folyamat két végpontján lévő jelentéseket nem lehet ugyanazoknak a beszélőknek tulajdonítani. Azaz: a térbeli és időbeli jelentés megjelenhet egyszerre egy adott nyelvállapotban, de akkor ez már nem köthető a beszélők szándékaihoz. A jelen írásban bemutatott összes elképzelés mögött ott áll ez a szintbeli ugrás: a konkrét kontextusokban megjelenő implikatúrák a beszélő szándékához köthetőek. Ezen implikatúrák szándékolása és a hallgató általi kikövetkeztetése eredményezi a nyelvhasználat dinamikáját, amely

25 Úgy értve: mint kódolt jelentés. E fejtegetés során ugyanis végig különbséget kell tennünk a jövőidejűség mint kódolt jelentés és a jövőidejüség mint egy adott kontextusban sugallt, kikövetkeztethető jelentés között. Ez utóbbi kötődhet a beszélő szándékához.

${ }^{26} \mathrm{~A}$ metonímia alább, a 7.2. pontban bemutatott értelmezései közül Lima lényegében a szinkrón megközelítést veszi alapul és utasítja vissza. 
a jelentések fokozatos megváltozásához vezet, de a kibontakozó változás semmi esetre sem tekinthető szándékoltnak. Ennek a megfogalmazása jelenik meg többek között Bybee (2007: 980) munkájában, és ezt a problémát nevezi meg Pinto de Lima (1999: 217) is, amikor annak a lehetetlenségére utal, hogy olyan beszélőt találjunk, aki metonimikus szándékkal hozza létre a megnyilatkozást 'mozgás' jelentéssel, de a jövő idő jelentés közlésének szándékával. A probléma úgy oldható fel, ha elismerjük, hogy a metonímia és metafora „szinkrón” értelmezésén túl, amely az egyes nyelvhasználók elméjében zajló kognitív folyamatokat takar, elismerjük e fogalmak „diakrón” megfelelőinek létét, amelyeket Traugott-Dasher (2004 [2002]: 27) nyomán metonimizációnak, illetve metaforizációnak is nevezhetnénk, és amelyek nem köthetőek egyetlen konkrét nyelvhasználóhoz. Ez a diakrón értelmezés azonban csupán a grammatikalizációs jelentésváltozás vizsgálatában érvényes, hiszen a lexikai jelentésváltozásban működő metafora és metonímia metaforikus, illetve metonimikus nyelvhasználaton alapul, amint fentebb Győri (2005) kapcsán bemutattuk (I. 2. pont). Ezt a problémakört a következő pontban vizsgáljuk meg.

\section{Következtetések, elméleti megfontolások}

\subsection{Adatok és egy dilemma}

Végül meg kell említeni, hogy a jelentésváltozás univerzális tendenciáinak feltárása, amely a grammatikalizációkutatás egyik legfőbb eredményének tekinthető, szintén kapcsolható a metafora vs. következtetések problémájához. A világ különböző nyelveiben felfedezett azonos jelentésváltozási ösvények megléte, azaz, hogy hasonló grammatikai jelentések alakulnak ki hasonló forrásfogalmakból, egyes szerzők szerint a kognitív mintázatok hasonlóságára és a metafora működésére utal (Dér 2005: 19, 53; Ladányi 1998: 407-413; Bybee-Perkins-Pagliuca 1994: xvxix). Ugyanakkor azonban e hasonlóságok alapján az ellentétes nézet mellett is lehet érvelni. Bybee (2007: 977) ezen tendenciákat éppen a következtetési mechanizmusok univerzális hasonlóságainak tulajdonítja: „a grammatikalizációs ösvények egyirányúsága és megjósolhatósága feltehetően a következtetések megjósolható mintázatainak tudható be"27 (I. még Bybee 2002). A szerző már egy korábbi munkájában is amellett érvel, hogy a változás univerzális mintázatait az őket létrehozó univerzális kognitív mechanizmusok rajzolják ki (Bybee 2002: 177). Azaz abba a problémába ütközünk, hogy, első ránézésre, ugyanazok az adatok két különféle hipotézist támasztanak alá. A konkrét kontextusokban zajló pragmatikai következtetések ugyanis, amelyek a grammatikalizáció pragmatikai megközelítése szerint a jelentésváltozást motiválják, hosszabb időtávlatból tekintve olyan változásokat eredményeznek, amelyek metaforikus átvitelként is leírhatóak. Úgy tűnik, a metafora vs. metonímia/pragmatikai következtetések folyamatára való hivatkozás jól kiegészítheti egymást a grammatikalizációs jelentésváltozás leírásában, alkalmazásuk attól függ, hogy a jelenséget mikro- vagy makroszinten vizsgáljuk-e (I. HopperTraugott 1993: 86-87; Dér 2008: 25). Bybee (2007: 978-979) Heine-ClaudiHünnemeyer (1991) megállapítására hivatkozva, akik hangsúlyozzák, hogy a

27 „some of the unidirectionality and predictability found in paths of grammaticalization may be due to predictable patterns of inferencing" 
változás fokozatossága arra utal, hogy a kontextusnak és a metonímiának (pragmatikai következtetéseknek) van nagyobb szerepe, arra a következtetésre jut, miszerint a grammatikalizációs jelentésváltozást ösztönző legnagyobb hajtóerő az implikatúrák konvencionalizálódása, vagyis a pragmatikai erősödés (pragmatic strengthening). Ez a fokozatos mechanizmus mozdítja elő a változást, jóllehet az eredmény leírható a metaforikus átvitel terminusaiban. Hasonló véleményen van Pinto de Lima (1999: 209), amikor hangsúlyozza, hogy a jelentésváltozás hosszú történeti folyamat, amely kicsi köztes lépésekből tevődik össze, így a metaforának csupán az illúziójáról van szó. Ahhoz azonban, hogy végső következtetést tudjunk levonni, és megérthessük, hogyan müködnek együtt a metaforikus és metonimikus folyamatok a grammatikalizációs jelentésváltozásban, számos grammatikalizációs esetet kell összehasonlítani.

Ha a fenti elemzéseket szemügyre vesszük, úgy tűnik, a működni látszó mechanizmusok az alkalmazott perspektíva, azaz a figyelembe vett adatok függvényei: a teljes folyamat leírható a metafora terminusaiban, míg közelebbről, a változás átmeneti kontextusainak szintjéről nézve a metonimikus folyamatok vehetőek észre. Még közelebbi nézőpontot alkalmaz Pinto de Lima (1999), aki lemegy egészen az egyes beszélők szintjére, és egy konkrét történeti folyamatot alapul véve részletesen górcső alá veszi, majd elveti mind a metaforán, mind a metonímián alapuló elemzést, így a nyelvi változatosság és az analógia marad elemzésének két sarokköve. $\mathrm{E}$ három nézőpont adathasználat tekintetében is eltér. A végső kérdés tehát egy örök dilemma, ami abban áll, hogy milyen adatokat vegyünk figyelembe a grammatikalizációs jelentésváltozás vizsgálatakor. Elvonatkoztathatunk az egyes beszélőktől, és átugorhatunk a nyelvi változás makroszintjére, egymástól akár évszázadnyi távolságra eső nyelvi formákat, jelentéseiket, használati lehetőségeiket vetve össze, és az ottani történéseket leírhatjuk a metafora fogalma segítségével, kihagyva az egyes nyelvhasználók szintjét és az ott zajló pragmatikai következtetéseket. De vajon elmondhatjuk-e, hogy ezzel a módszerrel a nyelvi változás kielégítő jellemzéséhez jutunk? Vagy pedig lemehetünk az egyes kontextusok szintjére, ahol a konkrét megnyilatkozáspéldány-jelentések vannak, és az ottani történéseket leírhatjuk a metafora fogalma nélkül. De szabad-e ebből levonnunk azt a következtetést, hogy ezzel a módszerrel a nyelvi változás kielégítő jellemzéséhez jutunk? E két szintnek a szembenállásából bontakozik ki a metafora és metonímia kétféle fogalma, egy szinkrón és egy diakrón értelmezés lehetősége, amit a továbbiakban részletesebben tárgyalunk. Kezdjük a metonímiával!

\section{2. „Szinkrón” és „diakrón” metonímia és metafora}

Nézzük meg, mi történik egy „hagyományos” metonímia esetén, szemben a grammatikalizációs jelentésváltozásban működő metonímiával! A szakirodalom közkedvelt példái a metonímia tárgyalásakor a következőhöz hasonló megnyilatkozások: $A$ sonkás szendvics a sarokban kér még egy kávét. A megnyilatkozás egy bárban hangozhat el egy felszolgáló szájából, aki így utal a sarokban ülő, sonkás szendvicset rendelő vendégre. Metonimikus nyelvhasználata azon alapul, hogy ebben a kontextusban a vendégek legkiugróbb tulajdonsága, hogy mit rendelnek. Ebben az esetben tehát metonimikus nyelvi kifejezésről van szó: egy entitásra referál a beszélő (sonkás szendvics), ez biztosít hozzáférést egy másik entitáshoz (a vendég), 
amelyek a külvilágban (és a kognitív térben) szomszédossági viszonyban vannak egymással. Szó szerint nemigen lehet érteni. Vessük ezt össze a történeti példával! A releváns történeti példák esetében a változás kiinduló kontextusában a szó szerinti jelentés IS jelen van, és a kikövetkeztetett jelentés IS, még ha egyes speciális kontextusokban az előbbi háttérbe szorul is. A grammatikalizációs jelentésváltozás folyamatában éppen ezeknek az átmeneti, kétértelmü kontextusoknak van kiemelt fontossága, ahol a forrásjelentés és az új jelentés egyaránt tulajdonítható. Ezt példázza a következő előfordulás:

(1482, Monk of Evesham [OED go 47b]) (Hopper-Traugott 1993: 83) Thys onhappy sowle ... was goyng to be broughte into helle for the synne and onleful lustys of her body.

'E boldogtalan lélek ... a pokolra vettetés felé haladt testének büne és törvénytelen vágyai okán.'

Az idézett példa a vizsgált jövő idő kialakulásának kezdeteire utaló legkorábbi elismert példa a szakirodalomban, amelyben a főnévi igenév passzív alakja ((to) be broughte) jelenik meg, ami ellentmond a szó szerinti értelmezésnek ('szándékos mozgás'). Amint Hopper és Traugott (1993: 83) kifejti, a megnyilatkozást a lélek halál utáni utazására vonatkozó hiedelem kontextusában kell értelmezni, ennek megfelelően a lélek tényleges mozgásáról lehet szó. A szerzők ugyanakkor hangsúlyozzák, hogy az ige passzív alakjának használata arra a következtetésre ösztönöz, hogy a mozgás nem az alany által szándékolt, és mivel az utazás végcélja (pokol) a broughte és nem pedig a goyng to igealak adjunktuma, a mozgás irányultsága is háttérbe szorul. Az ilyen kontextusok képezik a grammatikalizációs jelentésváltozás kiindulópontját: bennük a jelentések szomszédossága figyelhető meg, a szó szerinti jelentésé és a kikövetkeztetett jelentésé, amelyek kezdetben nem zárják ki egymást. Más szóval, nincsen szó metonimikus kifejezésről: a be going to egyik korai előfordulása sem tekinthető metonimikus kifejezésnek. Mégis, ebben a kontextusban az új jelentés, a jövőidejüség körvonalazódik, amennyiben a lélek mozgása mint valamely jövőbeli történés bekövetkezte felé való szimbolikus haladás értelmezhető. Nem a mozgás a releváns ugyanis, hanem az, hogy mi fog történni a lélekkel: elkárhozik-e, vagy megmenekül a kárhozattól.

A történeti pragmatika metonímiaértelmezése tehát jelentősen eltér a metonímia hagyományos felfogásától, amelyet a fenti $A$ sonkás szendvics a sarokban kér még egy kávét megnyilatkozás példáz, ahol a szó szerinti jelentés nem tulajdonítható az adott kontextusban. Mivel indokolható akkor, hogy metonímiáról beszélünk e jelenség kapcsán? Véleményem szerint a metonímia terminus megtartása a történeti példában megfigyelhető jelenség elnevezéseként is nemcsak azért célszerü, mert a szakirodalomban széles körben elterjedt szóhasználatról van szó, hanem a kognitív folyamatok hasonlósága miatt is. Ahogy fentebb említettük, metonimikus kifejezés esetén két, egymással a külvilágban és a kognitív térben szomszédos entitásról van szó, ahol az egyikre való referálás által biztosítjuk a hozzáférést a másikhoz. A kognitív szomszédosság a történeti metonímiaértelmezésben is megőrződik, bár itt jelentések szomszédosságáról beszélhetünk: lényegében a szó szerinti jelentés biztosít hozzáférést a kikövetkeztetett jelentéshez. E hasonlóság mellett ugyanakkor elmondható, hogy a kezdeti szakaszban a kettő együttesen van jelen, a szó szerinti jelentés is tulajdonítható. 
Hasonlóképpen különbség van a metafora szinkrón és diakrón értelmezése között, amelyet a következőkben vizsgálunk meg. Nézzük meg, mi történik egy „hagyományos” metafora esetén, szemben a grammatikalizációs jelentésváltozásban müködő metaforával! A következő megnyilatkozás metaforikus kifejezést tartalmaz: Sally egy jégtömb. Értelmezésekor a jégtömb szó szerinti jelentést is aktiválva, a forrástartomány egyes elemeit rávetítve a céltartományra keressük az adott kontextusban releváns értelmezést, amely kontextusonként eltérő lehet. Ezzel szemben, az angol közeljövő példájánál maradva: az It’s going to rain nem metaforikus kifejezés, hanem már grammatikalizálódott alak. Az ilyen előfordulások a grammatikalizáció későbbi szakaszához köthetőek, ahol az eredeti jelentés már nem tulajdonítható. Megértésüknél nem indulhatunk ki ezért a 'mozgás' jelentésből, egyszerű dekódolásról van szó, hiszen a jövőidejűség ekkorra már kódolt jelentés.

Ezzel az elemzéssel arra szerettem volna rávilágítani, hogy mind a metonímiának, mind a metaforának létezik egy „szinkrón” és egy „diakrón” fogalma, és ezek különbözőképpen viszonyulnak a konkrét nyelvhasználók mentális folyamataihoz. Nem elég e fogalmakat a metonímia vs. metonimizáció, illetve metafora vs. metaforizáció kifejezésekkel megkülönböztetni egymástól, hanem azt is hangsúlyozni kell, hogy a grammatikalizációs jelentésváltozásban a metonimizáció és a metaforizáció nem feltétlenül köthető metonimikus, illetve metaforikus használathoz, kifejezéshez a kiinduló nyelvállapotban úgy, mint a lexikai jelentésváltozás esetében.

A metonímia és metafora grammatikalizációs jelentésváltozásban betöltött szerepét vizsgálva feltehetjük tehát a kérdést, hogy ha e fogalmakat tágan értelmezve mint szomszédosságon, illetve hasonlóságon alapuló kognitív folyamatokra tekintünk, melyik jellemző inkább a vizsgált történeti folyamatra. Hogyan jelenik meg e folyamatban a TÉR és az IDŐ tartománya/fogalma? A fenti megfontolások alapján összefoglalóan a következőket állapíthatjuk meg: (i) a „,be going to + főnévi igenév” szerkezet grammatikalizációjában a jövőidejüség képzete következtetésként jelenik meg egyes konkrét nyelvhasználati kontextusokban, (ii) a folyamat kezdetén a 'mozgás' jelentés ténylegesen jelen van, nem csupán eszköz az időbeli jelentés konceptualizációjához, mint egy tisztességes metafora esetében, (iii) az olyan kontextusok, ahol a szó szerinti 'mozgás' jelentés nem tulajdonítható, később jelennek meg, bennük a kérdéses alak már grammatikalizálódott formának tekinthető, (iv) a korai kontextusokban nincs szó metaforikus, illetve metonimikus kifejezésről. Mindezek alapján tehát inkább szomszédosságról beszélhetünk, mint hasonlóságról, ami a következtetéses modellt támasztja alá.

\section{8. Összefoglalás}

Összefoglalásképpen elmondható, hogy a metafora és metonímia terminusok használatát vizsgálva terminológiai problémákra, „sokszínűségre” bukkanunk a szakirodalomban: a terminusok mögött álló fogalom sokszor csak az adott elméleti keret figyelembevételével következtethető ki. A háttérben álló elméletek különbözősége és a hozzájuk kapcsolódó terminológia miatt nehéz összevetni ezen elképzeléseket, de alaposabban megvizsgálva őket, a pragmatikai következtetések azok, amelyeket minden megközelítés elismer és a saját eszközeivel leír. Bár a metonímia és a metafora fogalma gyakran összemosódik a leírásban, a kognitív megközelítések elismerik, hogy a grammatikalizáció az adott használati kontextusban 
kikövetkeztethető jelentések konvencionalizálódásával, majd kódolttá válásával zajlik. Az egyedi nyelvhasználati kontextusokban felmerülő következtetések azonban sajátos változási mintázatokat kirajzoló változásokhoz vezetnek, így önmagukban nem elegendőek a folyamat jellemzéséhez. A hogyanra választ adnak, de nem magyarázzák kielégítően a grammatikalizációs jelentésváltozás univerzális ösvényeit.

A metonímia és metafora fogalma gyakran összemosódik a leírásban. Határaik nem egyértelműek, egyesek, pl. a relevanciaelméleti megközelítés, le is mondanak a köztük való különbségtételröl. Úgy gondolom, hogy a grammatikalizációs jelentésváltozás kutatása is errefelé mutat, hiszen az, hogy közelröl, illetve távolról szemlélve egyik, illetve másik látszik előtűnni, arra utal, hogy nincs közöttük éles átmenet, a metafora a metonimikus folyamatok kimenetének, végeredményének tűnik. A metonímia és metafora a grammatikalizációs jelentésváltozásban egymást kiegészítő pragmatikai folyamatokként összeegyeztethetőek, amennyiben a metaforát valamiféle következtetéses folyamatot is magában foglalóként fogjuk fel (Traugott-König 1991: 190).

A vizsgálat másik tanulsága, hogy a metafora és metonímia diakrón értelmezése jelentősen eltér e fogalmak szinkrón értelmezésétől, ahol metaforikus, illetve metonimikus kifejezésekkel van dolgunk. Ugyanakkor a lexikai jelentésváltozásban müködő metafora és metonímia sem feleltethető meg teljesen a grammatikalizációs jelentésváltozás leírásában használt fogalmaknak. A lexikai jelentésváltozásban ugyanis metaforikus, illetve metonimikus kifejezéssel van dolgunk a kiinduló, szinkrón nyelvállapotban, a grammatikalizációs jelentésváltozásban azonban nem. Mindezek alapján vajon következtethetünk-e arra, hogy a „diakrón metafora” valami teljesen más természetű dolog, mint a „szinkrón” metafora? Más szóval: van-e köze a „diakrón” metaforának a metaforikus nyelvhasználathoz, netán a fogalmi metaforához? E kérdés megválaszolásához térjünk vissza egyik kiindulópontunkhoz, Sweetser (1988) elemzéséhez. A metaforikus elemzés arra mutat rá, hogy melyek azok a következtetési sémák, amelyek relevánsak a grammatikalizációs jelentésváltozásban. Így ez az elemzés összeegyeztethető azzal, amelyik a következtetéseket helyezi a fókuszba, ráadásul magyarázattal szolgál arra, hogy miért éppen azok a következtetések kerülhetnek előtérbe. Ahogy Sweetser (1988: 390) megfogalmazza, a lexikai jelentések gazdag szemantikai tartalommal rendelkeznek, melyeknek topológiai aspektusaik is vannak. Az, hogy csupán a topologikus aspektusok őrződnek meg a lassan zajló és nem csupán egyetlen konkrét nyelvhasználóhoz köthető grammatikalizációs jelentésváltozásban, rávilágít e fogalmi struktúrák felépítésére, így a grammatikalizációs jelentésváltozás általános útjainak kutatása közelebb vihet minket az emberi fogalmi rendszer struktúrájának megértéséhez. A következtetések mechanizmusa nem véletlenszerü, feltételezhetjük, hogy a következtetések általános iránya mögött az emberi kogníció általános jellemzői bújnak meg. Úgy vélem, a metonímia fogalma ezért nem elég önmagában: az egyedi nyelvhasználati kontextusokban felmerülő, egyedi következtetéseket a mögöttük álló általános kognitív folyamatok irányítják, ami érthetővé teszi, hogy miért alakulnak hasonló módon, hasonló útvonalat végigjárva egyes grammatikai jelentések a világ különböző nyelveiben. A kognitív nyelvészet metafora fogalmában következtetéseink egyetemes törvényszerűségei fogalmazódnak meg. A „testesültség” szerepe sem elhanyagolható: a világ jelenségeit konkrét fizikai tapasztalatainkból, világtudásunkból kiindulva értelmezzük. A 'megy' ige használata felidézi a mozgáshoz 
kötődő teljes világtudásunkat: hogyan, miért, milyen céllal szokott helyváltoztatás történni. Ezen információk szerepelhetnek az egyes nyelvhasználati szituációban végrehajtott következtetésekben, azt gondolom, hogy enélkül a szerkezet jelentésváltozása nem magyarázható érdemben. Az itt bemutatott gondolatmenet azt látszik alátámasztani, hogy bár a metafora visszaszorul a lexikai szemantikai változások területére, azok az általános, a világ tapasztalati megismeréséből adódó tudáson alapuló következtetési sémák, amelyek a kognitív metaforák hátterében állnak, a grammatikalizációs jelentésváltozás irányát is megszabják. Hiszen a metafora alapja az ismétlődő hétköznapi tapasztalat, a „testesültség” a tér és idő konceptualizációjában. Ez arra látszik utalni, hogy a fogalmi metafora nem „okozza” a grammatikalizációs jelentésváltozást, hanem gyökereik közösek. Mindez jól összeegyeztethető a metafora és metonímia szinkrón kutatásának azon eredményeivel, miszerint sok, sőt, lehetséges, hogy minden metaforát a háttérben álló metonimikus folyamatok motiválnak (Barcelona 2003; Radden 2003 [2000]), olyannyira, hogy egyesek a két fogalom éles megkülönböztetésének lehetőségét is elvetik (Radden 2003 [2000]; a kettő elkülönítésének problematikájához I. Barcelona 2011: 36-48).

Hasonlóképpen megkérdezhetjük: van-e köze a „diakrón” metonímiának a metonimikus nyelvhasználathoz, netán a fogalmi metonímiához? Úgy tünik, a párhuzam erősebb, mint a metafora esetében, amennyiben a metonímia hagyományos fogalmában jelen lévő szomszédosságot a jelentések egyazon kontextusban való szomszédosságaként értelmezzük. A grammatikalizáció kiinduló kontextusaiban egy fogalmi entitás (a szó szerinti jelentés: 'mozgás') biztosít hozzáférést egy másik fogalmi entitáshoz (a kikövetkeztetett jelentéshez: 'a mozgás célja a jövőben', 'szándék'), amely ugyanannak az idealizált kognitív modellnek (esetünkben: „menni valahova valamilyen céllal”) a része. E kezdeti kontextusokban azonban a szó szerinti jelentés is tulajdonítható és elfogadható interpretációhoz vezet. Mindezen megfontolások azt látszanak alátámasztani, hogy történeti szempontból a metafora visszaszorul a lexikai szemantikai változások területére, míg a metonímia fogalma, jóllehet jelentős módosulásokon átesve, megtartható.

\section{Köszönetnyilvánítás}

A tanulmány az MTA-DE-SZTE Elméleti Nyelvészeti Kutatócsoport támogatásával jött létre. Ezúton fejezem ki hálámat és köszönetemet Németh T. Enikőnek segítségéért, a tanulmány alapjául szolgáló előadáshoz füzött gondolatébresztő megjegyzéseiért, valamint a tanulmány anonim lektorainak hasznos észrevételeikért, melyek által a tanulmány pontosabbá és érthetőbbé vált.

\section{Hivatkozások}

Barcelona, Antonio 2003. On the plausibility of claiming a metonymic motivation for conceptual metaphor. In Antonio Barcelona (szerk.) Metaphor and Metonymy at the Crossroads. A Cognitive Perspective. Berlin, New York: Mouton de Gruyter. 31-58. 
Barcelona, Antonio 2011. Reviewing the properties and prototype structure of metonymy. In Réka Benczes - Antonio Barcelona - Francisco José Ruiz de Mendoza Ibáñez (szerk.) Defining Metonymy in Cognitive Linguistics: Towards a Consensus View. Amsterdam, Philadelphia: John Benjamins. 7-57.

Bencze M. Ildikó 2010. A metonímia a kognitív pragmatikaelméletek tükrében. Magyar nyelvjárások 48:111-131.

Bybee, Joan L. 2002. Cognitive processes in grammaticalization. In Michael Tomasello (szerk.) The New Psychology of Language. Cognitive and Functional Approaches To Language Structure. Vol. 2 New Jersey: Lawrence Erlbaum Associates. 145-167.

Bybee, Joan L. 2007. Diachronic linguistics. In Dirk Geeraerts - Hubert Cuyckens (szerk.) The Oxford Handbook of Cognitive Linguistics. Oxford: Oxford University Press. 945-987.

Bybee, Joan L. - Revere D. Perkins - William Pagliuca 1994. The Evolution of Grammar: Tense, Aspect, and Modality in the Languages of the World. Chicago: University of Chicago Press.

Dér Csilla llona 2005. Grammatikalizációs folyamatok a magyar nyelvben - Elméleti kérdések és esettanulmányok. Budapest: ELTE.

Dér Csilla Ilona 2008. Grammatikalizáció. (Nyelvtudományi Értekezések 158) Budapest: Akadémia Kiadó.

Diewald, Gabriele 2002. A model for relevant types of contexts in grammaticalization. In Ilse Wischer - Gabriele Diewald (szerk.) New Reflections on Grammaticalization. Amsterdam, Philadelphia: John Benjamins Publishing Company. 103-120.

Grice, H. Paul 1989 [1975]. Logic and conversation. In H. Paul Grice (szerk.) Studies in the way of words. Cambridge: Harvard University Press. 22-40.

Győri Gábor 2005. Univerzális és relativisztikus tendenciák a szemantikai változásban: egy kognitív szemantikai vizsgálódás. In Kertész András - Pelyvás Péter (szerk.) Általános Nyelvészeti Tanulmányok XXI. Tanulmányok a kognitív szemantika köréból. Budapest: Akadémia Kiadó. 183-206.

Győri Gábor 2007. Az intuíció szerepe a szemantikai újításban. In Csatár Péter Pethő Gergely (szerk.) Szemantikai intuíciók mint nyelvészeti adatok. Debrecen: Kossuth Egyetemi Kiadó. 155-163.

Hansen, Maj-Britt Mosegaard - Richard Waltereit 2006. GCl theory and language change. Acta Linguistica Hafniensia 38/1:235-268.

Heine, Bernd 2002. On the role of context in grammaticalization. In Ilse Wischer Gabriele Diewald (szerk.) New Reflections on Grammaticalization. Amsterdam, Philadelphia: John Benjamins Publishing Company. 83-102.

Heine, Bernd - Ulrike Claudi - Friederike Hünnemeyer 1991. From cognition to grammar: Evidence from African languages. In Elizabeth Closs Traugott Bernd Heine (szerk.) Approaches to Grammaticalization Volume I. Theoretical and Methodological Issues. Amsterdam: John Benjamins Publishing Company. 149-187.

Heine, Bernd - Tania Kuteva 2002. World Lexicon of Grammaticalization. Cambridge: Cambridge University Press.

Hopper, Paul J. - Elizabeth Closs Traugott 1993. Grammaticalization. Cambridge: Cambridge University Press. 
Höfler, Stefan H. - Andrew D. M. Smith 2009. The pre-linguistic basis of grammaticalisation: A unified approach to metaphor and reanalysis. Studies in Language 33/4:886-909.

Johnson, Mark 1987. The Body in the Mind. The Bodily Basis of Meaning, Imagination, and Reason. Chicago: University of Chicago Press.

Kearns, Kate 2002. Implicature and language change. In Jef Verschueren - JanOla Östman - Jan Blommaert - Chris Bulcaen (szerk.) Handbook of Pragmatics. Amsterdam: John Benjamins Publishing Company. 1-22. doi:10.1075/hop.6.imp1.

Kövecses Zoltán 2005. A metafora. Gyakorlati bevezetés a kognitív metaforaelméletbe. Budapest: Typotex Kiadó.

Kövecses Zoltán - Benczes Réka 2010. Kognitív nyelvészet. Budapest: Akadémiai Kiadó.

Ladányi Mária 1998. Jelentésváltozás és grammatikalizáció - kognitív és szerves nyelvelméleti keretben. Magyar Nyelv 94/4:407-423.

Ladányi Mária 2005. A grammatikalizáció kutatása és a modern nyelvelméletek. In Oszkó Beatrix - Sipos Mária (szerk.) Uráli grammatizáló, 2003. szeptember 4-6. Budapest: MTA Nyelvtudományi Intézet. 7-32.

Lakoff, George 1987. Women, Fire, and Dangerous Things: What Categories Reveal about the Mind. Chicago, London: The University of Chicago Press.

Lakoff, George - Mark Johnson 1980. Metaphors We Live By. Chicago, London: University of Chicago Press.

Langacker, Ronald W. 2000. Grammar and Conceptualization. Berlin: Walter de Gruyter.

Levinson, Stephen C. 1983. Pragmatics. Cambridge: Cambridge University Press.

Levinson, Stephen C. 2000. Presumptive Meanings: The Theory of Generalized Conversational Implicature. Cambridge: The MIT Press.

Nagy C. Katalin 2014. Kontextus(ok) a grammatikalizációs jelentésváltozás irodalmában. Jelentés és Nyelvhasználat 1:11-27. doi:10.14232/JENY.2014.1.3.

Pinto de Lima, José 1999. Neither by metaphor nor really by metonymy: The shortcomings of these concepts as explanatory of language change processes. In Mário Vilela - Fátima Silva (szerk.) Actas do $1^{\circ}$ Encontro Internacional de Linguística Cognitiva. Porto: Faculdade de Letras do Porto. 207-221.

Radden, Günter 2003 [2000]. How metonymic are metaphors? In Antonio Barcelona (szerk.) Metaphor and Metonymy at the Crossroads: A Cognitive Perspective. Berlin/New York: Mouton de Gruyter. 93-108.

Reszegi Katalin 2011. A metonímia megítélésének kérdéséhez. In Navracsics Judit - Lengyel Zsolt (szerk.) Lexikai folyamatok egy-és kétnyelvü közegben. Budapest: Tinta Könyvkiadó. 75-83.

Smith, Andrew D. M. - Stefan H. Höfler 2015. The pivotal role of metaphor in the evolution of human language. In Javier E. Díaz-Vera (szerk.) Metaphor and Metonymy across Time and Cultures Perspectives on the Sociohistorical Linguistics of Figurative Language. Berlin, Boston: De Gruyter. 123-140.

Sweetser, Eve E. 1988. Grammaticalization and semantic bleaching. Annual Meeting of the Berkeley Linguistics Society 14:389-405. doi:10.3765/bls.v14i0.1774. 
Talmy, Leonard 1985. Lexicalization patterns: semantic structure in lexical forms. In Timothy Shopen (szerk.) Language Typology and Syntactic Description. Cambridge: Cambridge University Press. 57-148.

Tolcsvai Nagy Gábor 2005. Kognitív jelentéstani vázlat az igekötős igéről. Magyar Nyelv 101/1:27-43.

Traugott, Elizabeth Closs 1999. The role of pragmatics in semantic change. In Jef Verschueren (szerk.) Pragmatics in 1998: Selected Papers from the 6th International Pragmatics Conference. Vol. 2 Antwerpen: International Pragmatics Association. 57-148.

Traugott, Elizabeth Closs - Richard B. Dasher 2004 [2002]. Regularity in semantic change. Cambridge: Cambridge University Press.

Traugott, Elizabeth Closs - Ekkehard König 1991. The semantics-pragmatics of grammaticalization revisited. In Elizabeth Closs Traugott - Bernd Heine (szerk.) Approaches to Grammaticalization. Amsterdam: John Benjamins Publishing Company. 189-218.

\section{A szerzőről}

Nagy C. Katalin tudományos munkatárs az MTA-DE-SZTE Elméleti Nyelvészeti Kutatócsoportban. Történeti pragmatikával foglalkozik, eddig elsősorban a katalán összetett múlt kialakulását vizsgálta történeti pragmatikai szempontból. További kutatási témái a történeti beszédaktus-kutatás és udvariasságkutatás, valamint a történeti pragmatikai módszertan körébe tartoznak, különös tekintettel a kontextus szerepére és értelmezéseire a történeti pragmatikában.

Elérhetősége: nagykati@hist.u-szeged.hu 